Int. J. Plant Sci. 164(4):505-517. 2003.

(c) 2003 by The University of Chicago. All rights reserved.

$1058-5893 / 2003 / 16404-0003 \$ 15.00$

\title{
SHAPE MATTERS: HOFMEISTER'S RULE, PRIMORDIUM SHAPE, AND FLOWER ORIENTATION
}

\author{
Bruce K. Kirchoff ${ }^{1}$
}

Department of Biology, P.O. Box 26170, University of North Carolina at Greensboro, Greensboro, North Carolina 27402-6170, U.S.A.

\begin{abstract}
Hofmeister's rule is an empirical heuristic derived from the observation that new leaf primordia are formed in the largest space between the existing flanks of the older primordia. These observations have been repeatedly validated in studies of leaf arrangement, but there has been little attempt to extend them to inflorescence and floral organs. This investigation demonstrates the validity of Hofmeister's observations to cincinnus and early flower development in Phenakospermum guyannense (Strelitziaceae) and Heliconia latispatha (Heliconiaceae) and relates these results to Paul Green's work on the biophysics of organ formation. The cincinni of Phenakospermum and Heliconia arise in the axils of primary bracts and produce a prophyll, continuation apex, and flower in regular succession. The shapes and orientations of the apical regions of the cincinni are correlated with the placement of these organs, which in turn effect the positions of the sepals and their sequence of formation. The result is two rows of mirror-image flowers. The mirror-image symmetry of the flowers is a direct result of Hofmeister's rule in connection with the shape of the apical region. These two factors create a self-sustaining developmental system that produces prophylls, continuation apices, flowers, and sepals in regular succession. Although the cincinni and flowers of these species are built on a common plan, slight differences in apical shape and orientation produce differences in mature floral orientation. Understanding these orientations, and identifying the sequence of sepal formation, allows a proper identification of organ homologies. A study of Green's results and theories shows that Hofmeister's rule can be considered as an empirical condensation of the biophysical factors that influence organ position. These biophysical factors are widely applicable to organ formation in many species.
\end{abstract}

Keywords: Hofmeister's rule, flower development, inflorescence development, phyllotaxy, developmental constraints, organ position, Zingiberales, Phenakospermum, Strelitziaceae, Heliconia, Heliconiaceae.

\section{Introduction}

Hofmeister's rule is an empirical heuristic derived from the observation that new leaf primordia are formed on the vegetative apex in the largest space between the existing flanks of the older primordia (Snow and Snow 1962; Jean 1984; Wagenitz 1996). This heuristic reflects what appears to be a limiting condition for the establishment of Fibonacci and related phyllotactic patterns and forms the basis of most theories and models of phyllotaxy (Richards 1951; Rutishauser 1981; Rutishauser and Sattler 1985; Lacroix and Sattler 1988; Douady 1998; Atela et al. 2002). Despite the wide applicability of this rule to studies of leaf arrangement, there have been few attempts to apply it to reproductive development (Lyndon 1978a, 1978b; Green 1988; Kirchoff 2000). This failure may result from our propensity to divide plants into discrete units (Kirchoff 2001). By separating the flower from its context, we limit the factors that can be correlated with the positions of its organs. Considering flowers in the context of the inflorescence allows us to investigate the applicability of Hofmeister's rule and biophysical factors to this system (Green 1988, 1999). If Hofmeister's rule is applicable to flower development, the first sepal will appear in the first space available on the apex, as far as possible from the position(s) of the subtending

${ }^{1}$ E-mail kirchoff@uncg.edu.

Manuscript received November 2002; revised manuscript received March 2003. bract(s). The position of this sepal will effect the orientation of the flower in the inflorescence. Inflorescences that are built on similar plans but with even slightly different bract insertions will have flowers with different orientations. Flower orientation thus becomes comprehensible through a contextual study of development.

An understanding of flower orientation is important for constructing characters for phylogenetic analysis. Properly constructed characters depend on the determination of homologies, and, at least in some flowers, correct determination of homologies depends on establishing organ-by-organ equivalencies between taxa. For instance, when a taxon possesses staminodes, questions of organ-by-organ equivalencies naturally arise. Determining these equivalencies depends on knowing the correct orientation of the flower. Without this knowledge, it is often impossible to determine which petal a staminode replaces.

In this article, I investigate the effects of Hofmeister's rule on organ position and flower orientation in two families of the Zingiberales. Within this order, the families of Heliconiaceae and Strelitziaceae have similar inflorescence and flower structures and are closely related. The most recent estimate of their evolutionary relationship places the Strelitziaceae as the sister group to the clade that contains the Heliconiaceae and the four families Costaceae, Zingiberaceae, Cannaceae, and Marantaceae (Kress et al. 2001). The presence of a staminode in the Heliconiaceae and the absence of a stamen in the Stre- 
litziaceae make the study of these families especially interesting from the point of view of flower orientation.

\section{Material and Methods}

\section{Techniques}

Inflorescences and flowers of Phenakospermum guyannense (L. C. Rich) Endl. ex Miq. (Strelitziaceae) and Heliconia latispatha Benth. (Heliconiaceae) were collected at Waimea Arboretum, Oahu, Hawaii (P. guyannense, accession number $75 \mathrm{p} 1229$; H. latispatha, accession number 74p1142), and at Fairchild Tropical Garden (H. latispatha only, accession number 59-1065). A voucher specimen of the Waimea collection of $H$. latispatha is deposited at BISH (Kirchoff 87-107). Material of both species was preserved in formalin-acetic acid-alcohol (FAA) (Berlyn and Miksche 1976) and stored in Kew fluid ( $50 \% \mathrm{EtOH}, 40 \% \mathrm{H}_{2} \mathrm{O}, 5 \%$ glycerol, $5 \%$ formalin) on returning to University of North Carolina at Greensboro.

Development of P. guyannense (approximately three inflorescences) was studied by scanning electron microscopy (SEM). The cincinni were removed from fixative, washed in $50 \%$ EtOH, dehydrated using 2,2-dimethoxypropane (DMP), and transferred to $100 \%$ EtOH (Postek and Tucker 1976). Before dissection, the specimen were stained with fast green. Stained buds were dissected under $100 \%$ EtOH, dried using a Pelco Critical Point Dryer, mounted on observation stubs, and further dissected under a binocular dissecting microscope. The specimen were coated with gold in a Pelco Sputter Coater 91000 and observed in the Leica Stereoscan 430 SEM at 5-7 $\mathrm{kV}$. The majority of the specimens were dissected, recoated, and observed in the SEM several times. Video images from the SEM were digitally captured and stored in the tagged image file format (TIFF). Plates were prepared by incorporating the images from the TIFF files in a composite plate using Adobe Photoshop.

Development of $H$. latispatha (ca. 20 inflorescences) was studied before the acquisition of the SEM using the epiillumination light microscopy technique of Sattler (1968), Posluszny et al. (1980), and Charlton et al. (1989). Preserved material was removed from the fixative, dehydrated to $100 \%$ ethanol, and stained for several days in fast green (Johansen 1940; Charlton et al. 1989). Destaining was carried out in $100 \%$ ethanol for $2 \mathrm{~d}$ to several weeks. Photographs were taken with Kodak Technical Pan film on a Leitz Ortholux 2 photomicroscope equipped with an Ultropak illuminator. Kodak Dektol was used to develop the film for $3 \mathrm{~min}$ at $68^{\circ} \mathrm{C}$ (Kodak 1983). The negatives were scanned to disk with a Nikon Super Cool Scan LS1000 slide scanner or onto Kodak Photo CDs by one of several commercial photographic laboratories. The images were edited and assembled into plates using Adobe Photoshop.

\section{Terminology}

Inflorescence. The branches of an inflorescence are numbered according to their position within the ramification. The primary (or first-order) axis bears the foliage leaves and terminates in an inflorescence. The bracts that are borne directly on this axis are the primary (or main) bracts. Cincinni (monochasia or uniaxial cymes) arise in the axils of the primary bracts and terminate in primary (or first-order) flowers (fig. 1). Secondary bracts are borne on the axes that terminate in primary flowers and subtend the second flower of the cincinnus (fig. 1). This branching pattern continues with the production of tertiary and higher-order bracts and flowers.

Since the secondary, tertiary, etc., bracts are the first phyllomes on a branch, they are also prophylls (first leaves). I use the term "prophyll" to refer to a bract when its position within the ramification is not important. I call the apex that arises in the axil of a prophyll a continuation apex because it continues the growth of the cincinnus by producing a prophyll and terminal flower.

Flower orientation. The terms "median" and "transverse" refer to the orientation of a flower relative to the axis that bears it (Weberling 1989). The median plane bisects the flower and its axis (figs. 2, 3). The transverse plane bisects the flower at right angles to the median plane. The adaxial side of a flower is the side toward the lower-order axis that bears the flower. The abaxial side lies away from this axis. For the purposes of this article, I treat the posterior side of the flower as the side that backs on the main florescence axis and the anterior side as the side away from this axis (fig. 2). Thus, in this article, posterior and anterior are not synonymous with adaxial and abaxial.

\section{Results}

\section{Inflorescence Structure and Flower Orientation}

The inflorescences of both Phenakospermum guyannense and Heliconia latispatha are simple thyrses (figs. 1-3). In both genera, cincinni occur in the axils of distichous primary bracts

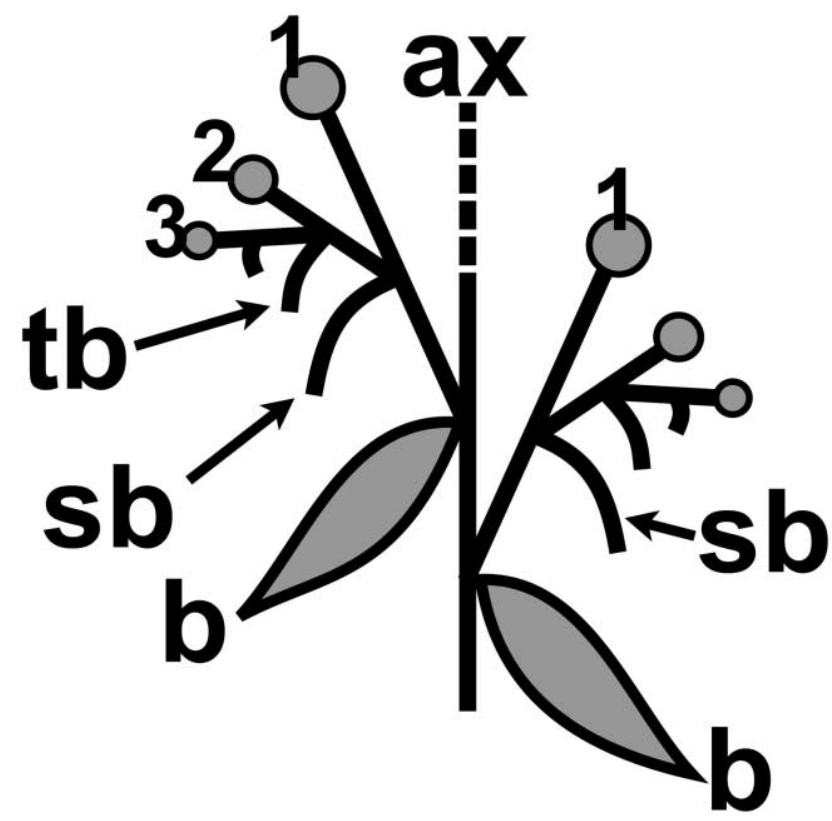

Fig. 1 Diagram of a thyrse with two cincinni. 1 = primary flower of a cincinnus; 2 = secondary flower; 3 = tertiary flower; $a x=$ main axis of inflorescence; $b=$ main or primary bract; $s b=$ secondary bract; $t b=$ tertiary bract. 


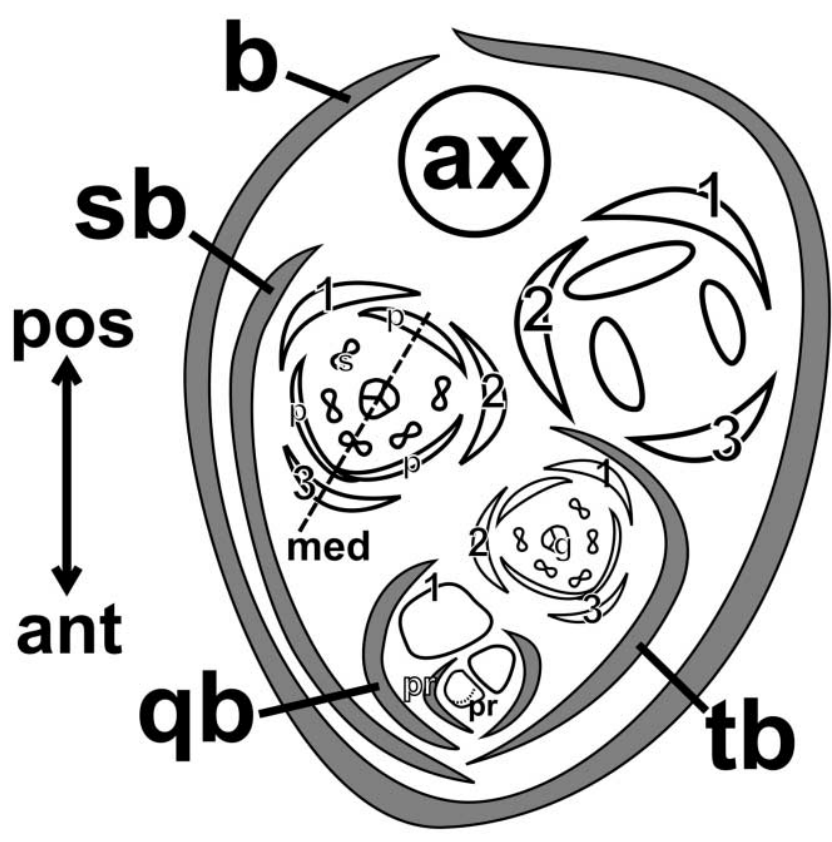

Fig. 2 Phenakospermum guyannense, diagram of cincinnus and flower structure. The first flower of each cincinnus has only three organs internal to the sepals. The flowers are oriented so that their median plane $($ med $)$ passes between the next-older flower and the inflorescence axis. Adjacent flowers are mirror images of each other. 1-3 = sequentially formed sepals; ant $=$ anterior side of the cincinnus and flower; $a x=$ main axis of the inflorescence; $b=$ primary bract of the inflorescence; $g=$ gynoecium; $p o s=$ posterior side of the cincinnus and flower; $q b=$ quaternary bract; $s b=$ secondary bract; $t b=$ tertiary bract; $p=$ petal; $p r=$ prophyll; $s=$ stamen.

and bear up to 25 (Phenakospermum) or 14 (Heliconia) flowers. The prophylls are borne in converging zigzag patterns that come into contact in the region of the continuation apex, the growing tip of the cincinnus (figs. 2, 3). In Phenakospermum, the medial plane of the flower bisects the flower into two mirror-image halves but does not bisect the lower-order axis on which the flower is borne (fig. 2, med). Rather, the medial axes of the flowers converge toward the main axis of the inflorescence (fig. 2). Because of this, the medial planes do not bisect either the inflorescence axis or the lower-order axis that bears them. In Heliconia, by contrast, the flowers are situated so that their medial planes pass more or less directly through the lower-order axis that bears them (fig. 3). The medial plane does not, however, bisect the flower into two symmetrical halves. The presence of the staminode on the posterior side of the flower is not matched by the presence of a similar organ on the anterior (fig. 3).

In Phenakospermum, all but the first and occasionally the second flower of each cincinnus have a three-lobed aposepalous calyx, three petals, five stamen, and a trilocular, inferior ovary (figs. 2, 4A). The two anterior petals are adherent to each other and enclose the stamen before pollination. The first and occasionally the second flower of each cincinnus have a different structure. These flowers have three sepals and three sterile, interior organs (fig. 2). The interior organs are intermediate in structure between sepals and petals. The largest of them occurs in the normal position of the adaxial petal, while the other two are located slightly more adaxially than a normal petal would be (fig. 2).

In Heliconia, the flowers contain a three-parted calyx, three petals, five stamen, a sterile staminode, and a trilocular, inferior ovary (figs. 3, 4B). There is a short perianth tube that serves as a nectar reservoir. At the top of this tube, the posterior sepal becomes free, while the two anterior sepals remain adherent to the petals for most of their length.

Both genera have flowers that occur in two rows, alternating in a zigzag pattern from the oldest to the youngest (figs. 2, 3). Within a row, the flowers all have the same symmetry, while between rows they are mirror images (figs. 2, 3, 5A).

\section{Cincinnus Development}

Phenakospermum guyannense. A primary cincinnus apex is initiated in the axil of each primary bract, forms a prophyll, and terminates in a flower. A sympodial continuation apex forms in the axil of the prophyll and repeats the same developmental pattern as does the primary apex (figs. 1, 5A). The position of the secondary bract (the first prophyll of the cincinnus) determines the symmetry of the cincinnus. If the sec-

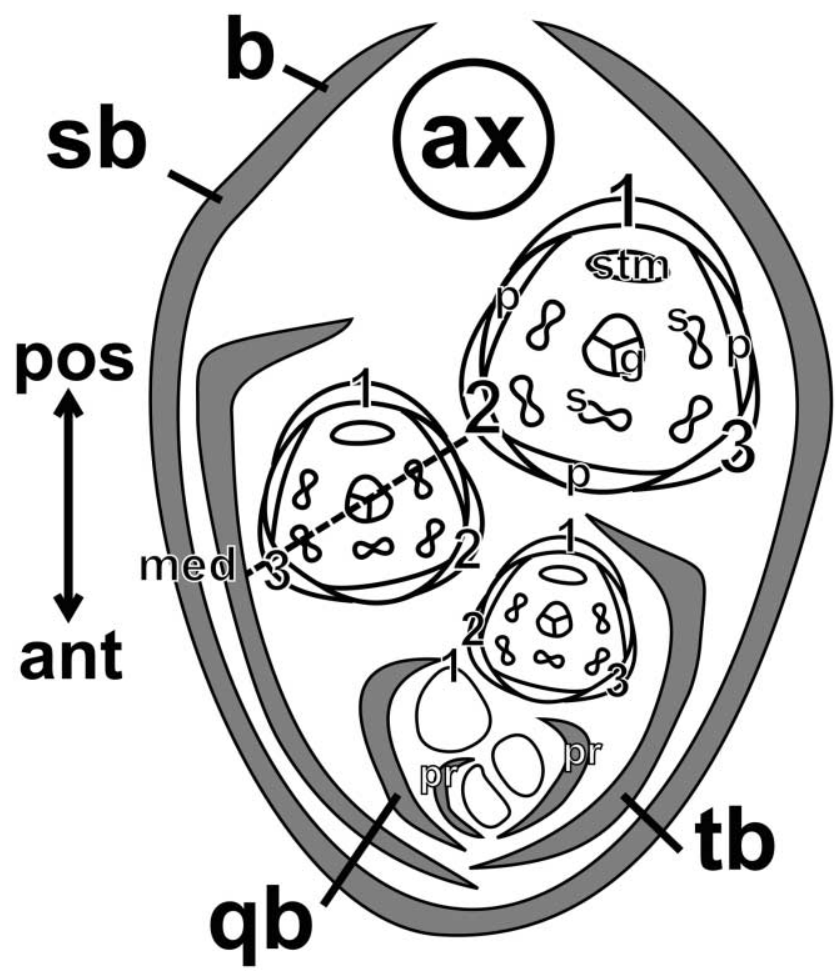

Fig. 3 Heliconia latispatha, diagram of cincinnus and flowers structure. The flowers are shown at the level of the perianth tube, which is formed from the adnation of all six perianth members. The median plane $(m e d)$ of the flower bisects the next-older flower. Adjacent flowers are mirror images of each other. 1-3 = sequentially formed sepals; $a n t=$ anterior side of the cincinnus and flower; $a x=$ main axis of the inflorescence; $b=$ main or primary bract; $g=$ gynoecium; $p=$ petal; $p o s=$ posterior side of the cincinnus and flower; $p r=$ prophyll; $s t m=$ staminode; $q b=$ quaternary bract; $s=$ stamen; $s b=$ secondary bract; $t b=$ tertiary bract. 

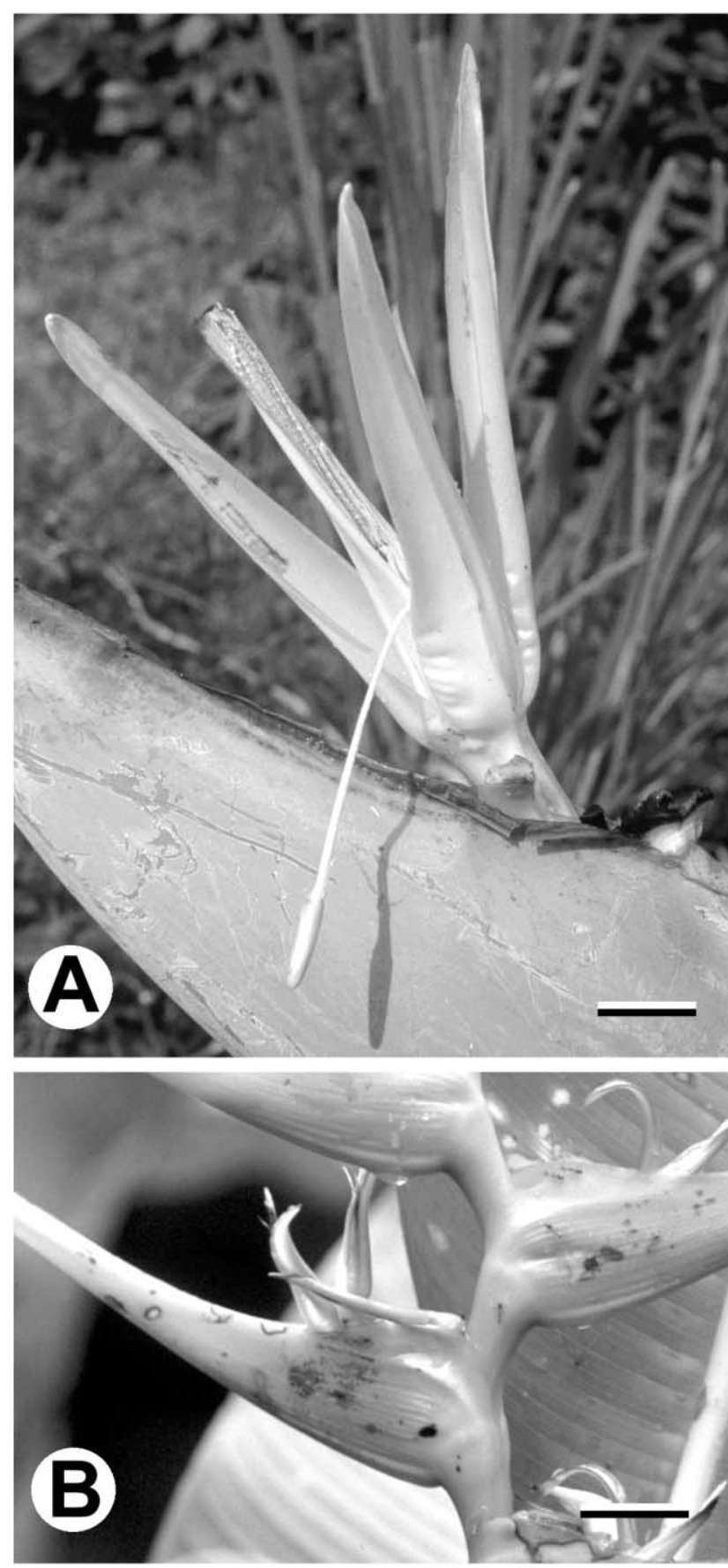

Fig. 4 Flowers and primary bracts of Phenakospermum guyannense and Heliconia latispatha. A, Phenakospermum guyannense. B, Heliconia latispatha. Bars $=5 \mathrm{~cm}$.

ondary bract forms on the right side of the apex (viewed from the position of the primary bract), the cincinnus is right handed. If the secondary bract occurs on the left side, the cincinnus is left handed. Both right- and left-handed cincinni occur in the same inflorescence.

As the cincinnus matures, flowers are added by the continuation apex in the following way: a prophyll forms on the anterior side of the continuation apex at an angle of ca. $30^{\circ}-35^{\circ}$ to the median axis of the cincinnus (fig. $5 A-5 \mathrm{C}, \mathrm{pr}$ ). The most anterior portion of the prophyll first becomes distinct from the continuation apex (fig. $5 D$, youngest prophyll), followed by the posterior portion, which sometimes remains attached to the flower and continuation apex during organ formation (fig. 5E). After forming a prophyll, the apex of the cincinnus transforms into a flower (fig. 5E, f1). A new continuation apex arises in the axil of the prophyll and, like the prophyll, becomes distinct in the anterior regions prior to the posterior (fig. 5E, $c a$ ).

The young flower primordium enlarges and changes shape before the formation of the first sepal. Enlargement begins in the part of the flower that is as far as possible from the most recently formed prophyll (figs. 5E, 6A, stemmed arrows). The first sepal will form in this position. This region of the flower is the part closest to the main axis of the inflorescence; i.e., it is the most posterior portion of the flower. Although the flower primordium enlarges and changes shape during this period, the side of the primordium adjacent to the next-older flower remains larger (fig. $5 B, 5 D$, flower $f 1$ ), and the side away from this flower remains smaller (fig. $5 \mathrm{~B}$, arrowheads; fig. $6 \mathrm{~A}, 6 \mathrm{~B}$, f1) throughout early floral development.

The first sepal forms in the region that is as far as possible from the subtending prophyll and axillary continuation apex (fig. 5B-5F; fig. 6A, 6B, stemmed arrows). The second sepal forms close to the median line of the cincinnus (fig. 5A, 5C, 2 ). The third sepal forms abaxially, adjacent to the prophyll that subtends a lower-order axis (fig. $5 B-5 D$, arrowheads, 3 ). The remaining paragraphs of this section relate this initiation pattern to Hofmeister's rule.

The formation of a module of the system begins with the appearance of a continuation apex in the axil of a prophyll (fig. 5E, $c a$, pr; fig. 6A). This apex produces a prophyll and a new continuation apex, and it terminates in a flower. The first organ to form on the continuation apex is the prophyll (fig. $5 B, 5 E$; fig. 6 , brackets), followed by the new continuation apex and the flower, which form at the same time. The position of the prophyll (and, thus, of the other organs) is influenced by the position and shape of the primordia already present around the continuation apex (Hofmeister's rule). As the continuation apex becomes distinct, its subtending prophyll is appressed against and frequently attached to its abaxial-lateral side (fig. $5 E, p r$ ). This attachment of the older prophyll likely inhibits the formation of a new primordium in the posteriorlateral region of the continuation apex (fig. $5 E$, see attachment of $p r$ to $f 1$ and $c a$ ). Consequently, the new prophyll forms on the anterior-lateral side of the continuation apex (fig. 5B, $5 E$, $5 F$; fig. 6 , brackets). This is the region of the continuation apex that is farthest from all other primordia.

The positions of the sepals are also correlated with the positions and shapes of the other organs on the apex (the floral apex, in this case). As the floral apex enlarges, it initiates a sepal in the region farthest from the most recently formed prophyll (figs. 5, 6A, stemmed arrows, 1). During this period, the flower continues to enlarge. The size gradient established by the growth of the flower (figs. $5 D, 6 B, f 1$ ) and the initiation of the first sepal is correlated with the position of the second sepal (fig. 5B, 5C, 2; fig. 6C, arrow). The largest region of the flower abuts against the next-older flower on the opposite side 
of the cincinnus, while the smallest region is adjacent to the subtending prophyll (fig. $5 B, 5 C, f 1$ ). The second sepal forms in the portion of this larger region that is maximally distant from the first sepal (fig. 5B, 5C, 2; fig. 6C). This places the second sepal in the angle formed by the two flowers on the opposite-side cincinnus (fig. 5A-5C; fig. 6C). The divergence angle between the first and second sepals is ca. $95^{\circ}-100^{\circ}$. The presence of these two sepals leaves the smallest portion of the flower, adjacent to the subtending prophyll, free for the formation of the third sepal (fig. $5 B$, arrowheads; fig. 6C, $6 \mathrm{D}$, $f 1, p r 2)$. The third sepal forms in this position, as far as possible from the two existing sepals (fig. 5C, 5D, 3; fig. 6D, arrow).

This pattern of prophyll, flower, and sepal initiation means that successive flowers form as mirror images of each other (figs. 2, 5A). These symmetries are clearly visible in the relative sizes of the sepals and their imbricate estivation (fig. $5 A$ ). The mirror-image symmetry of the flowers results directly from the developmental sequence that produces the flower primordia and sepals. This sequence is part of a self-sustaining developmental system that produces prophylls, continuation apices, and flowers in a regular alternation.

Heliconia latispatha. As in Phenakospermum, the primary cincinnus apex forms in the axil of a primary bract, initiates a prophyll and axillary continuation apex, and terminates in a flower. The continuation apex repeats the same developmental pattern to form an additional prophyll, continuation apex, and flower (figs. 7, 8). Unlike Phenakospermum, the apical region of the cincinnus is borne at a very steep angle in relation to the rest of the cincinnus (cf. figs. $5 A, 7 A$ ). The angle is so great that the flower/continuation apex complex is appressed directly against the subtending prophyll (fig. 7A, rpr). Only after careful dissection and reorientation is the cincinnus apex visible (fig. $7 B-7 D$ ).

The first prophyll of a cincinnus may form either to the left or to the right, thereby determining the symmetry of the cincinnus. Both right- and left-handed cincinni occur in the same inflorescence.

Each prophyll forms on the anterior, lateral side of the cincinnus at a $35^{\circ}-40^{\circ}$ angle to the medial axis of the cincinnus (fig. $7 A-7 D, p r$ ). The anterior portion of the prophyll becomes distinct prior to the posterior, which remains attached to the flower and continuation apex for a short time (fig. 7C). After forming the prophyll and continuation apex, the remainder of the apex forms a flower (fig. 7C, f1). The new continuation apex becomes distinct in the anterior region prior to the posterior, just as the previous apex did.

The young flower primordium enlarges and changes shape, while the prophyll and continuation apex continue to enlarge (fig. 7D). Enlargement of the floral apex is most pronounced in the region most distant from the last-formed prophyll (fig. $7 B, 7 C, 1)$. The first sepal forms from this region. The second sepal forms close to the center line of the cincinnus (fig. $7 \mathrm{~A}$, $7 C, 2)$. Initially, this sepal forms in the gap between the two flowers on the opposite side of the cincinnus (fig. $7 A, 7 E, 7 F$, stemmed arrows), but, later, the site of its initiation extends so that it lies adjacent to the next-older flower (fig. $7 A, 7 G$, $7 H, 2)$. The third sepal forms distal to the center line of the cincinnus in the position left free by the initiation of the other two sepals (fig. $7 A, 7 G, 7 H$ ). The remaining paragraphs relate this initiation pattern to Hofmeister's rule.
As in Phenakospermum, the pattern of organ initiation produces flowers with mirror-image symmetries (figs. 3, 7A). The developmental sequence that produces these flowers begins with the formation of the continuation apex in the axil of a prophyll (fig. $8 A, 8 B$ ). The anterior side of the continuation apex separates first from its subtending prophyll and is thus more available for the formation of the next prophyll than the posterior side (fig. $7 \mathrm{C}, \mathrm{ca}$ ). The degree of separation of the continuation apex is one correlate of the position of the next prophyll. The second correlate is the position and shape of the primordia adjacent to the continuation apex. The posterior portion of this apex is occupied by either the most recently formed flower (fig. $7 C, f 1$ ) or the posterior side of the subtending prophyll (fig. $7 \mathrm{C}, p r$ ). The positions of these two organs are correlated with the position of the new prophyll on the anterior, lateral side of the apex (fig. $7 \mathrm{C}$, bracket; fig. $8 \mathrm{~A}$, $8 B)$.

Sepal position is correlated with similar factors. Following enlargement, the floral apex forms the first sepal in the region that is farthest from other organs at the apex (the prophyll and continuation apex) (fig. $7 A-7 C, 1$; fig. $8 A, 8 B$, arrows). The position of this sepal is also correlated with the shape of the apex early in floral development (fig. $8 A, 8 B$ ). The sepal forms on the higher portion of the apex, the portion that is adjacent to the next-older flower of the cincinnus (fig. $7 A, 1^{\prime}$; fig. $8 A$, arrow).

The shape of the floral apex is also correlated with the position of the second sepal. The second sepal initiates ca. $90^{\circ}-95^{\circ}$ from the first sepal, on the portion of the floral apex that lies between the next-older and younger flowers (figs. $7 \mathrm{~A}$, $8 C$, arrows). This places the first two sepals on the adaxial side of the flower, the side that lies adjacent to the next-older flower (fig. 7A). The positions of these two sepals are correlated with the fact that the adaxial-posterior side of the flower becomes distinct from the continuation apex prior to the abaxial-anterior side (figs. $7 D, 8 B, 8 C, f 1$ ). From floral initiation through the formation of the third sepal, the least developed portion of the flower is its abaxial side, the side adjacent to the subtending prophyll (fig. $7 D, f 1$, pr; fig. $8 B-8 D$ ). The third sepal forms in this portion of the flower, as far as possible from the first two sepals (fig. $7 G, 7 H$; fig. 8D).

\section{Discussion}

\section{Hofmeister's Rule}

Hofmeister (1868) formulated what came to be called his "rule" in two slightly different ways: in terms of the distance of the new primordium from those already present on the apex ${ }^{2}$ and in terms of the largest space left by the preceding pri-

\footnotetext{
2 "Es ist eine durchgreifende Erfahrung, dass neue Blätter (oder Seitenachsen) an denjenigen Orten über den Umfang des im Zustande des Vegetationspunktes befindlichen Stängelendes (oder Stängelgürtels) hervortreten, welche am weitesten von den Seitenrändern der Basen der nächst benachbarten, bereits vorhandenen Blätter entfernt sind" (Hofmeister 1868, pp. 482-483). [It is a common experience that new leaves (or axillary buds) emerge at those places in the circumference of the vegetative apex that is situated at the end of a stem (or at a node), which are removed furthest from the margins of the bases of the next-adjoining leaves, already present on the apex.]
} 

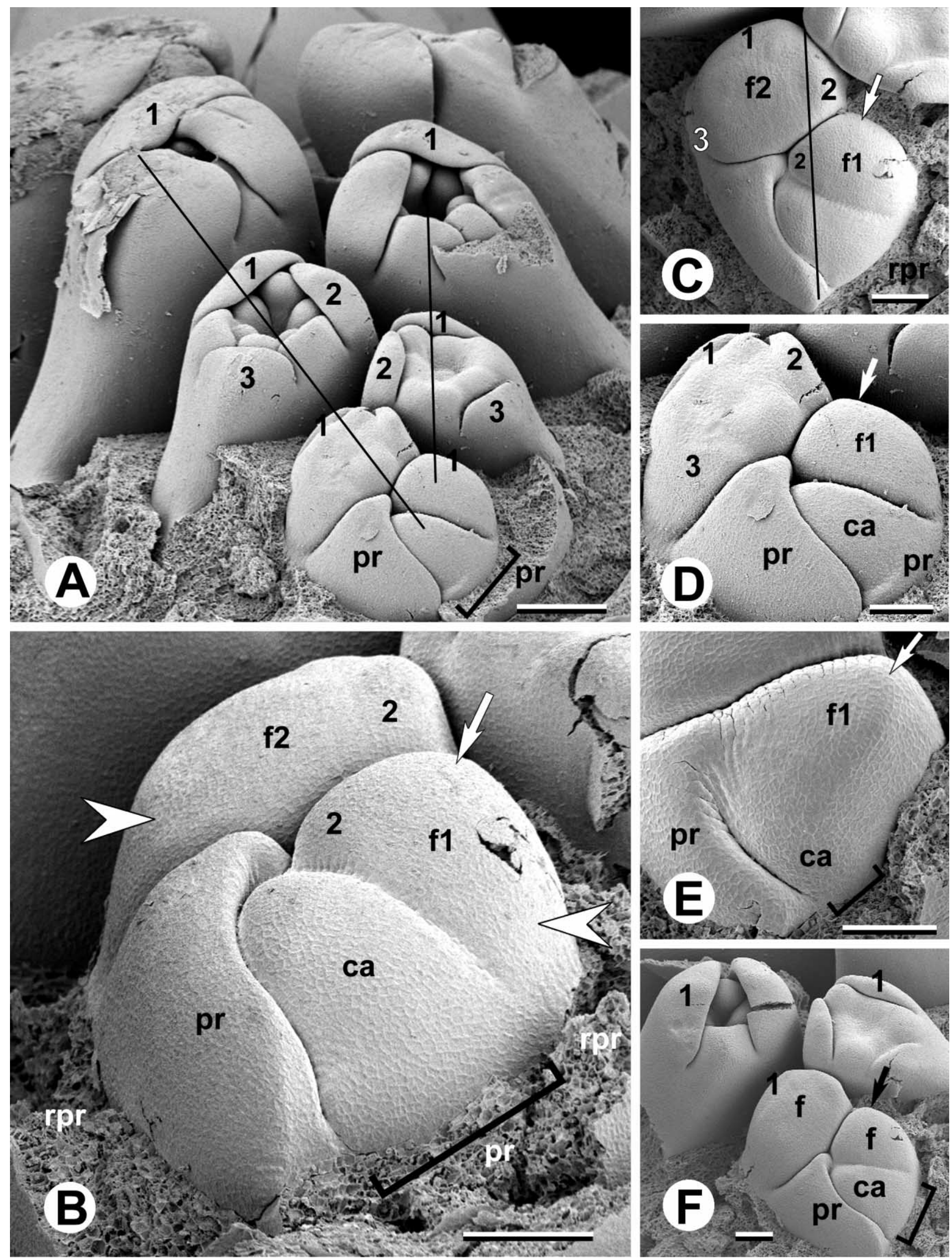
mordia. ${ }^{3}$ Wagenitz (1996) combines these two observations into a single definition: "Eine neue Blattanlage bildet sich am Vegetationskegel über der grössten Lücke zwischen den benachbarten älteren." "This definition combines the ideas of the largest available space (Hofmeister 1868, p. 500) with the distance between the flanks of the existing primordia (Hofmeister 1868, pp. 482-483).

Although Hofmeister (1868) gave two slightly different definitions of his rule, there does not appear to be a functional difference between these definitions. In spiral phyllotactic systems, the largest space is the space that is farthest from the next-adjoining primordia. Leaf 0 will occur in the space left free by leaves $2,3,5$, and 8 , the leaves occurring in the same sector as leaf 0 . In distichous systems, Hofmeister's rule applies only if we restrict the "next-adjacent primordia" to the last formed primordium, $180^{\circ}$ from the new site. With this proviso, both versions of Hofmeister's rule make the same prediction. In the case of polymerous whorls, all of the members of the previous whorl influence leaf positions in the new whorl ( $\mathrm{Ru}-$ tishauser 1999). Leaves arranged in alternating whorls follow Hofmeister's rule; superposed whorls violate it.

Interestingly, Hofmeister may not have been the first to formulate his rule. Rutishauser (1999, p. S97) draws attention to Braun (1831, p. 360), who provides a formulation that is similar to what we now refer to as Hofmeister's rule.

In the phyllotactic literature, Hofmeister's rule is often presented as a hypothesis about the appearance of a new primordium "in the largest space left by the preceding ones, at regular time interval T" (Douady 1998, p. 336; Jean and Barabé 1998; Atlea et al. 2002). This formulation omits reference to the distance from the previously existing primordia and introduces the idea of periodicity. Although there are good reasons for making these changes, it does not appear that Hofmeister (1868) formulated his rule in this way. As far as I am aware, he did not explicitly refer to the periodic appearance of new primordia. The phyllotactic literature also commonly

\footnotetext{
3 "Das Auftreten der neuen seitlichen Sprossungen über der weitesten der Lücken zwischen den nächstbenachbarten älteren gleichartigen Sprossungen derselben Achse ist eine Erscheinung von nahezu vollständiger Allgemeinheit" (Hofmeister 1868, p. 500). [The appearance of new lateral organs in the largest of the spaces between the nearest older organs of the same type on the same axis is a phenomenon of almost complete universality.]

${ }^{4} \mathrm{~A}$ new leaf primordium is formed on the vegetative apex in the largest space between the existing flanks of the older ones (Wagenitz 1996).
}

credits Snow and Snow (1962) with the first available space theory of leaf placement (Douady 1998). However, Hofmeister's (1868) formulation clearly includes this idea.

\section{Flower Orientation}

The difference in flower orientation between Phenakospermum guyannense and Heliconia latispatha (figs. 2, 3) can be understood on a developmental basis. Events early in the initiation of the prophyll and continuation apex are correlated with the position of the first sepal and, thus, the orientation of the flower. In both cases, the first sepal forms from the region of the flower primordium that first becomes free from the continuation apex and prophyll. This position is maximally distant from these organs (figs. $6 B, 8 B$, arrows). In P. guyannense, these events place the first sepal adjacent to the next-older flower of the same symmetry (figs. 2, 5A). In H. latispatha, the angle at which the apical complex of the cincinnus is borne is much greater than in $P$. guyannense. This difference is correlated with the more posterior initiation of the first sepal. It forms more toward the axis of the inflorescence (cf. figs. 6B, $8 B$, arrows; also fig. $7 A$, position $1^{\prime}$ ). The position of the first sepal is correlated, in turn, with the positions of the second and third sepals and results in the orientation of the flower (fig. 3).

The orientation of the flowers of Heliconia was previously reported by Eichler (1875), Schumann (1900), Winkler (1930), Lane (1955), and Kunze (1985). Although most of these authors used diagrams to illustrate their claims, Kunze (1985) published a photograph of the cincinnus of Heliconia metallica and reported the same orientation in Heliconia humilis. Coupled with a knowledge of sepal initiation, the orientation of the flowers provides an important clue to the homologies of the floral organs in the Zingiberales.

\section{Homology of the Floral Organs}

The homologies of the floral organs have never been analyzed on an organ-by-organ basis, though homologies are implied by published floral diagrams (fig. 1 in Kress 1990). Kress's (1990, 1995) and Kress et al.'s (2001) morphological data sets depend on these implied homologies. According to these diagrams, the median plane of the flower in Heliconia bisects the staminode (fig. 9B). Accepting this interpretation makes this staminode homologous to the median, outer whorl

Fig. 5 Cincinnus development in Phenakospermum guyannense. A, Cincinnus with eight flower primordia. All but the youngest prophylls $(p r)$ have been removed. The lines connect flowers of the same symmetry. $1-3=$ sequentially formed sepals. Bar $=200 \mu \mathrm{m}$. $B$, Apical region of a cincinnus with two young flowers $(f 1, f 2)$ and a continuation apex $(c a)$ initiating a prophyll (bracket and $p r)$. The largest side of each flower is adjacent to the next-older flower of the cincinnus. Arrow $=$ position of first sepal initiation; arrowheads = positions of third sepal initiation on two sequentially formed (mirror-image) flowers. $r p r=$ removed prophyll. Bar $=100 \mu \mathrm{m}$. C, Polar view of apical region shown in fig. $B$. 1-3 = positions of sequentially formed sepals; arrow = position of first sepal initiation; $f 1, f 2=$ flowers; line = central axis of the cincinnus; $r p r=$ removed prophyll. Bar $=100 \mu \mathrm{m} . D$, Enlargement of apical region of the cincinnus shown in A. The prophyll $(p r)$ is more distinct from the continuation apex $(c a)$ anteriorly than posteriorly. $1-3=$ sequentially formed sepals; arrow $=$ position of first sepal initiation; $f 1=$ flower. Bar $=100 \mu \mathrm{m}$. E, Apical region of a cincinnus at the time of continuation apex $(c a)$ formation. The continuation apex forms in the axil of the prophyll $(p r)$. Arrow $=$ site of first sepal initiation; bracket $=$ position of next prophyll formation; $f 1=$ flower. Bar $=100 \mu \mathrm{m} . F$, Slightly oblique view of cincinnus shown in $B$ and $C$. Arrow = position of first sepal initiation on youngest flower; $1=$ first formed sepal; bracket $=$ site of formation of next prophyll; $c a=$ continuation apex; $f=$ flower; $p r=$ prophyll. Bar $=100 \mu \mathrm{m}$. 


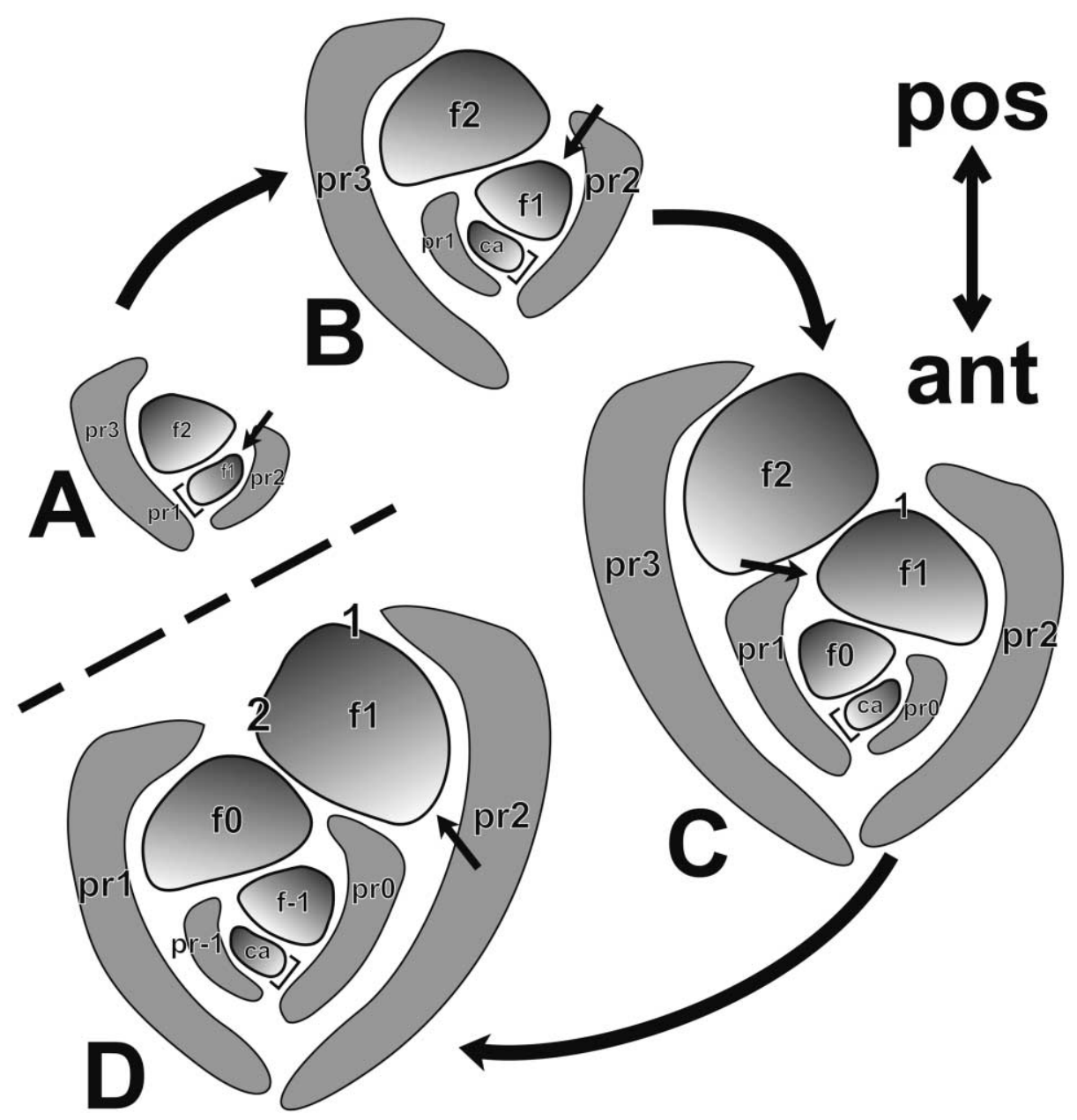

Fig. 6 Diagrammatic summary of cincinnus and flower development in Phenakospermum guyannense. Each drawing shows the structure of the cincinnus one plastochron later than the previous drawing. The flower formed during the first plastochron is flower $1(f 1)$. The prophyll borne on the same axis as this flower is prophyll 1 (pr1). Flowers and prophylls formed during later plastochrons are given lower numbers $(f 0$, pro, $f-1, p r-1)$, while those formed earlier are given higher numbers $(f 2, p r 2)$. Deepness of shading of the flower primordia indicates the height of the primordium above the common pad (cf. fig. $5 A, 5 B$ ). ant = anterior; pos = posterior. A, Plastochron 1 . Initiation of flower 1 ( $f 1$ ). Arrow $=$ future position of the first sepal of flower $1 . B$, Plastochron 2. Initiation of first sepal (arrow) on flower 1 (f1). C, Plastochron 3. Initiation of second sepal (arrow) of flower $1(f 1)$. D, Plastochron 4. Initiation of third sepal (arrow) of flower $1(f 1) .1,2=$ positions of sequentially formed sepals; bracket $=$ position of next prophyll to be formed from the continuation apex; $c a=$ continuation apex.

stamen in Phenakospermum (fig. 9A) and to the "missing" outer stamen in the Zingiberaceae (fig. 9C) (Kirchoff 1997, 1998). These interpretations are consistent with Kress et al.'s (2001) morphological characters 16-18.

Taking the orientation of the flowers and the sequence of sepal initiation into account changes our assessment of these homologies (fig. 9D-9F). The staminode of Heliconia now becomes homologous to the anterior, lateral outer stamen of Phenakospermum (fig. 9D, 9E) and to one of the lateral, petaloid staminodes of the Zingiberaceae (fig. 9F). Accepting this interpretation places the staminode of the Heliconiaceae in the context of the whole cincinnus and allows us to equate the structure of the cincinnus across the families (see also Kirchoff 1997, 1998). This results in a reinterpretations of Kress et al.'s (2001) characters 16 and 18 (table 1).

\section{Hofmeister's Rule in Other Species}

In Hedychium coronarium (Zingiberaceae), the first prophyll forms apparently randomly on either side of the cincinnus apex, as is the case in both P. guyannense and H. latispatha (Kirchoff 2000). Subsequent prophylls are situated in relationship to both the positions of the other primordia in the cincinnus and the shape of the continuation apex that bears them.

The correlates of sepal initiation in $H$. coronarium are slightly more complex. In the first flower of the cincinnus, the position of the first sepal is correlated with the shape of the floral apex and the position of the continuation apex. The position of the second sepal is correlated with the shape of the apex and the position of the first sepal. The third sepal is placed 

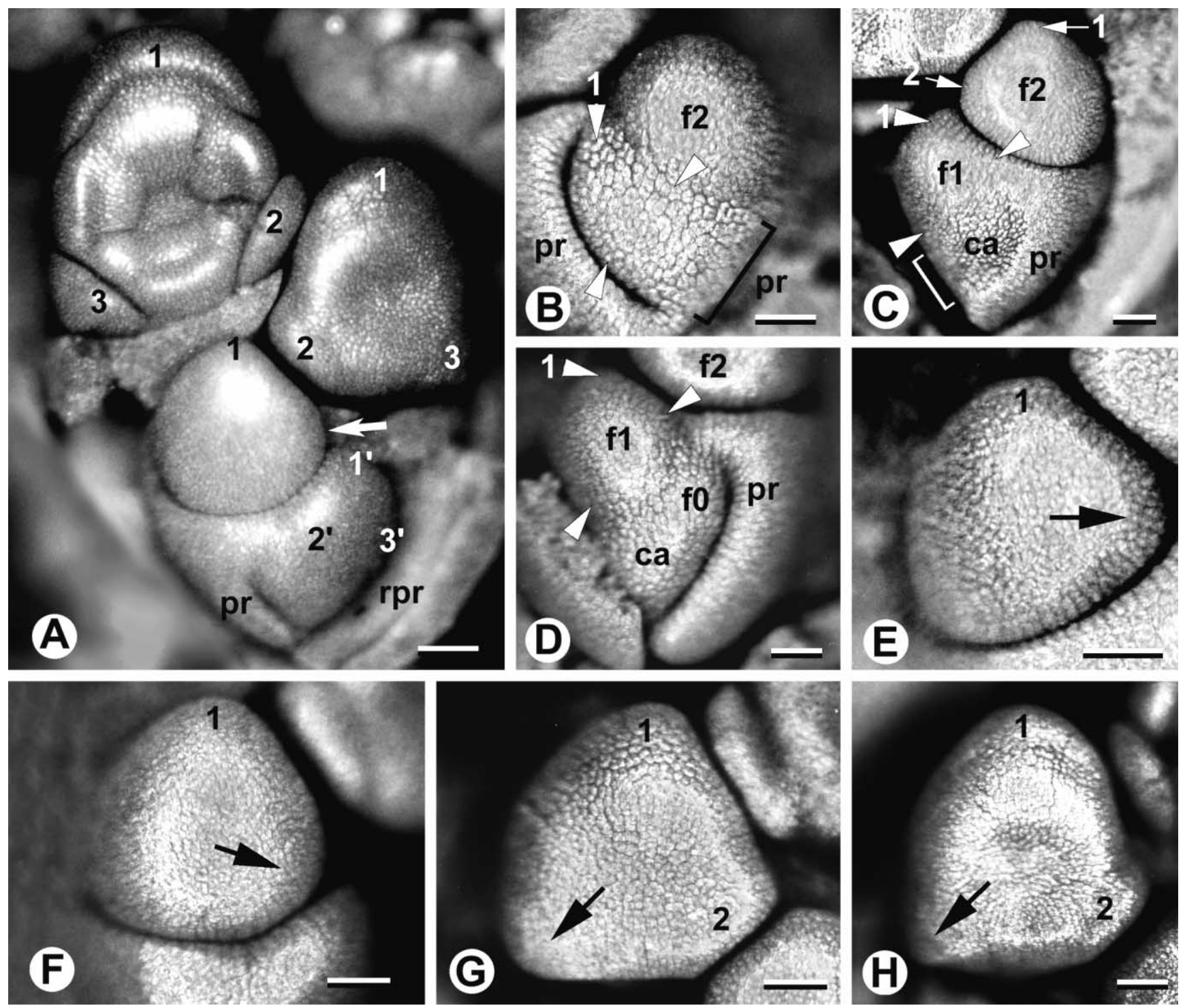

Fig. 7 Cincinnus development in Heliconia latispatha. A, Cincinnus with four flower primordia. All but the youngest prophyll ( $p r$ ) have been removed or partially removed $(r p r) .1-3=$ sequentially formed sepals; $1^{\prime}-3^{\prime}=$ future positions of sepal formation on the youngest flower; arrow $=$ future position of second sepal formation. $B a r=200 \mu \mathrm{m} . B-D$, Continuation apices showing the sequential formation of flowers $(f 2$, $f 1, f 0$ ), prophylls (brackets, $p r$ ), and higher-order continuation apices $(c a)$. The apical regions shown in these pictures are borne at very steep angles to the rest of the cincinnus (see fig. $7 A$ ). They were reoriented for photography. $B$, Continuation apex prior to the formation of a flower and prophyll. 1 = future position of first sepal; arrowheads = other regions of the continuation apex that will form sepals; $f 2=$ flower primordium; $p r=$ prophyll. Bar $=100 \mu \mathrm{m}$. C, Continuation apex at the stage when a new flower $(f 1)$, continuation apex (ca), and prophyll $(p r)$ are formed. 1,2 = sequentially formed sepals; arrowheads = regions of the young flower $(f 1)$ that will form sepals; bracket $=$ position of next prophyll formation; $f 2=$ older flower. Bar $=100 \mu \mathrm{m} . D$, Later stage in the formation of a new continuation apex $(c a)$ and flowers $(f 2$, $f 1, f 0) .1=$ position of first sepal formation; arrowheads $=$ regions of the young flower that will form sepals; $p r=$ prophyll. Bar $=100 \mu \mathrm{m}$. $E$, Young flower at the stage of the formation of the first sepal (1). Arrow $=$ site of second sepal initiation. Bar $=100 \mu \mathrm{m}$. F, Formation of first sepal (1) on a slightly older flower. Arrow = position of second sepal initiation between the two flowers on the opposite side of the cincinnus. Bar $=100 \mu \mathrm{m} . G$, Formation of the second sepal (2). Arrow = position of third sepal initiation. $1=$ first formed sepal. Bar $=100 \mu \mathrm{m}$. $H$, Formation of the third sepal (arrow). 1, $2=$ sequentially formed sepals. Bar $=100 \mu \mathrm{m}$.

on the basis of the position of the first two sepals, though its position is also correlated with the shape of the adaxial part of the flower. The positions of the sepals in the higher-order flowers are also correlated with the positions of the prophylls, previously formed sepals, and are related to the shape of the floral apices (Kirchoff 2000). These findings established the hypothesis that Hofmeister's rule and the shape of the apex both play important roles in positioning the prophylls and sepals.

In Mimosa strigillosa (Fabaceae, Mimosoideae), the first 


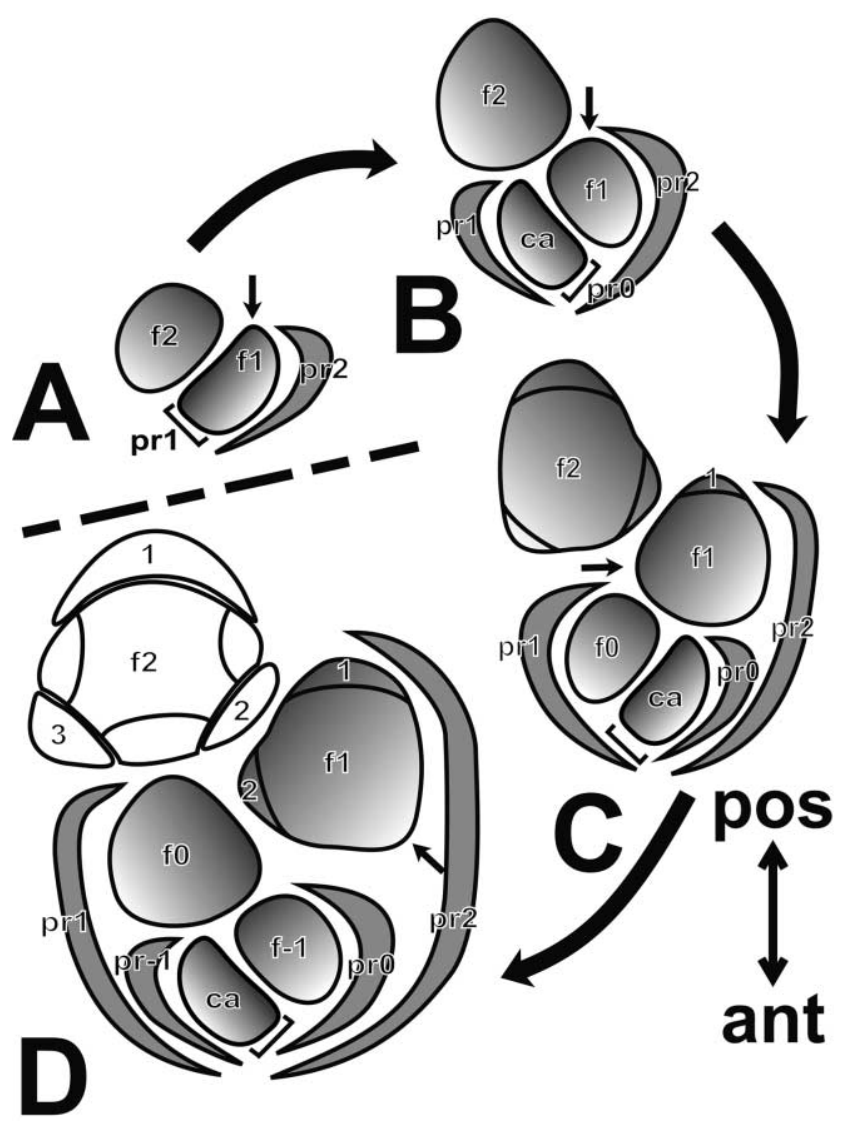

Fig. 8 Diagrammatic summary of cincinnus and flower development in Heliconia latispatha. Each drawing shows the structure of the cincinnus one plastochron later than the previous drawing. The flower in the process of formation during the first plastochron is flower 1 (f1). The prophyll borne on the same axis as this flower is prophyll 1 (pr1). Flowers and prophylls formed during later plastochrons have lower numbers $(f 0, \operatorname{pr} 0, f-1, p r-1)$. Older flowers and prophylls have higher numbers $(f 2, p r 2)$. Deepness of shading indicates the height of the floral apex. Higher regions are deeper black. ant = anterior; bracket $=$ position of next prophyll to be formed from the continuation apex; $c a=$ continuation apex; pos $=$ posterior. $A$, Plastochron 1. Flower $1(f 1)$ is still attached to the continuation apex. Arrow $=$ future position of the first sepal. $B$, Plastochron 2. Initiation of first sepal (arrow) on flower 1 (f1). C, Plastochron 3. Initiation of second sepal (arrow) in the portion of flower 1 that lies between the two flowers on the opposite side of the cincinnus. D, Plastochron 4. Initiation of third sepal (arrow) of flower 1. 1-3 = positions of sequentially formed sepals.

event in flower development is the enlargement of the floral apex to produce a rounded, deltoid primordium (RamírezDomenech and Tucker 1989). The shape of the flower at this stage is correlated with its position in the axil of the subtending bract and with the initiation of three of the four sepals (figs. 6, 7, 12, 13, 14 in Ramírez-Domenech and Tucker 1989).

Acacia baileyana (Fabaceae, Mimosoideae) also seems to confirm the hypothesis that Hofmeister's rule is important in identifying the positions of sepal formation. In this species, solitary flowers are initiated in the axils of bracts (Derstine and Tucker 1991). Before sepal initiation, the floral apex is tangentially elongated and has a form similar to the cincinnus apex of Hedychium (fig. 18 in Derstine and Tucker 1991; Kirchoff 1998, 2000). The most common pattern of sepal initiation is helical, beginning with a sepal in one of the two lateral sites, corresponding to the "points" of the tangentially elongated apex (their fig. 20). The flowers may be either right or left handed, depending on which sepal (right or left) forms first. This is similar to the cincinni of $H$. coronarium, which may be right or left handed, depending on the position of prophyll formation.

In her studies of the Detarieae (Fabaceae, Caesalpinioideae), Tucker has identified two apex shapes that are associated with differences in the position of the first sepal. In Omega-type apices, the floral apex is radially elongate at bracteole initiation (Tucker 2000a, 2001b, 2002a, 2002b). This apex type is associated with two subtending bracteoles that occlude $90 \%$ of the apex and that touch adaxially. In some of these species, the sepal number is reduced to one. At the time of the initiation of the first sepal, most of the floral apex is occluded by the bracteoles leaving only the abaxial portion free. The first sepal is initiated abaxially and medially in this free space. When additional sepals are present, they are formed sequentially (Brachystegia; Tucker 2000a), which suggests that their positions can be predicted by Hofmeister's rule.

The circular type of floral apex is also subtended by two bracteoles. However, in this case, they occlude only $20 \%$ of the apex and do not touch adaxially (Tucker 2000b, 2001a, $2001 b$ ). Following their initiation, the floral apex is circular, and five sepals are formed sequentially. The first of these sepals is abaxial and nonmedian. It forms slightly toward the older of the two bracteoles, in accordance with the prediction of Hofmeister's rule.

Despite the demonstrated predictive power of Hofmeister's rule, no hypothesis is perfect. Flower development in Psoralea pinnata (Fabaceae, Papilionoideae) seems to disconfirm the hypothesis that there is a close relationship among organ position, apex shape, and the sequence of sepal initiation (Tucker and Stirton 1991). In this species, each flower is subtended by a cupulum composed of three to four bracts. These bracts initiate in helical succession and elongate by intercalary growth to form a lobed tube around the base of the flower. Sepal initiation is usually unidirectional (abaxial to adaxial), though occasional flowers with helical initiation of sepals were also reported (Tucker and Stirton 1991). In most of the published photographs, there is no apparent relationship between apical shape and sequence of sepal initiation (figs. 8, 10 in Tucker and Stirton 1991). The reason for this lack may be due to the elongation of the pedicel after cupulum initiation. This may free the floral primordium from positional influences exerted by the cupulum bracts.

\section{Hofmeister's Rule and the ABC Model}

Bowman (1997) discusses floral diversity in the framework of the ABC model of flower development (Bowman et al. 1989; Carpenter and Coen 1990; Schwarz-Sommer et al. 1990). Although he cites a number of examples in which shifts in the spacial expression of one of the A-, B-, or C-class genes could produce existing flowers, he concludes that this model cannot account for the enormous diversity of floral forms. His solution 

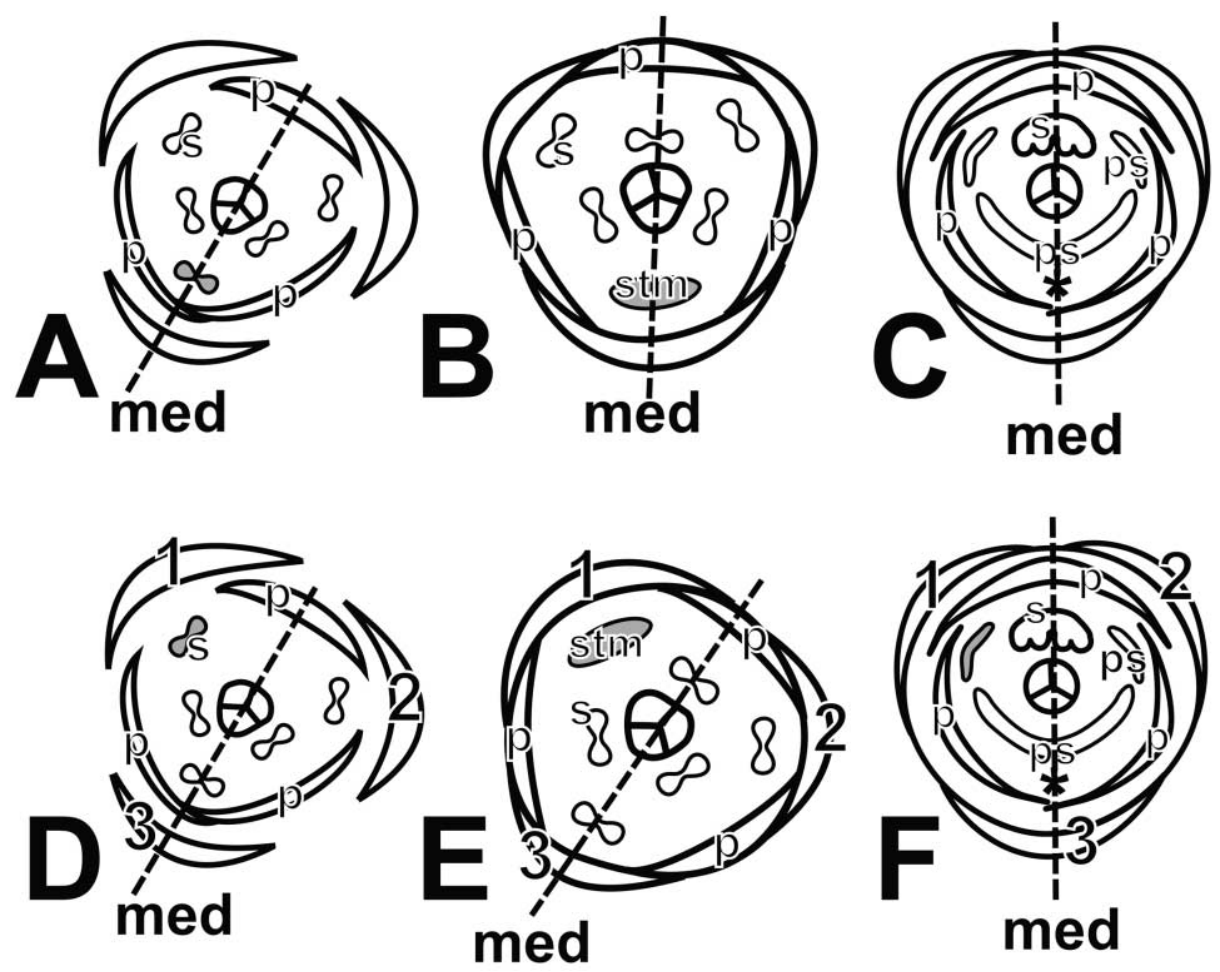

Fig. 9 Comparison of flower orientation and structure in Phenakospermum $(A, D)$, Heliconia $(B, E)$, and Hedychium $(C, F)$. A-C are shown with homologies according to Kress (1990) and $D$ and $E$ with homologies according to this article. The androecial members homologous to the staminode of Heliconia are shaded. The sequence of sepal development in Hedychium is from Kirchoff (1997, 2000), while the identification of the median plane in Heliconia is from Kress (1990, his fig. 1). 1-3 = sequentially formed sepals; asterisk = missing staminode of Hedychium; med $=$ median plane of the flower; $p=$ petal; $p s=$ petaloid staminode; $s=$ stamen; $s t m=$ staminode.

to this problem is that other genetic programs must be involved. He speculates that these programs may influence floral organ size, shape, color, or symmetry. Their activation may be tied to expression of the $\mathrm{ABC}$ genes, or they may be independent of these genes. For example, the program controlling zygomorphy in Antirrhinum has been shown to be independent of the organ identity genes, while the programs controlling organ size and shape appear to be activated by these genes (Luo et al. 1996).

In addition to organ identity, size, shape, and color, a complete causal description of flower development must account for the number of organs and their circumferential position. Undoubtedly, there is a genetic component to the control of these aspects, but, as Green $(1994,1999)$ has suggested, this genetic aspect may be indirect. That is, the genetic effect may be modulated by biophysical factors such as the patterns of microtubule arrangement and the shape of the floral apex.

\section{Biophysical Influences on Organ Position}

Through descriptive morphology, experimental manipulations, and modeling, Paul Green demonstrated the plausibility of a biophysical model of pattern formation in plants (Green 1985, 1994, 1996, 1999). His work shows that cellulose microfibril alignment and surface buckling could be important factors in forming an intermediary between gene action and final form.
Green's work on the biophysics of developing organs indicates that we should expect simultaneous formation of a variable number of organs if there are no positional effects from other organs, and if there is no preexisting cell pattern on the apex (Green 1985, 1994, 1999). If these two conditions are met, the only geometrical influences on the formation of new organs will be (1) that they will form from the periphery inward and (2) that further organs will form in alternation with those already present (Green 1985, 1994; Hernández and Green 1993). The partitioning of the sunflower capitulum into florets is one of the best examples of an unpatterned apex forming new organs centripetally (Hernández and Green 1993).

The effect of releasing an unpatterned apex from the influences of adjacent organs is most likely seen in Philodendron fragrantissimum (Barabé et al. 2000). As in all Philodendron spp., this species lacks bracts and bracteoles below the flowers. The floral apices are circular, are arranged in a hexagonal grid on the inflorescence surface, and remain independent of each other throughout the early stages of organogenesis. In both staminate and pistillate flowers, the floral organs (stamens or carpels) are formed simultaneously around the periphery of the apex. The number of organs also varies in different flowers. There are 5-8(-10) stamens and $(5-) 6-9(-10)$ carpels per flower. Both of these phenomena could be related to the release of the floral apex from influences imposed by the proximity 


\section{Table 1}

Reinterpreted Characters 16 and 18 from Kress et al. (2001)

\begin{tabular}{llll}
\hline & & \multicolumn{2}{c}{18 (in part): outer whorl lateral stamen } \\
\cline { 3 - 4 } & 16: outer whorl median stamen & \multicolumn{1}{c}{ Anterior stamen } & Posterior stamen \\
\hline Strelitziaceae & Present/fertile & Fertile & Fertile \\
Heliconiaceae & Present/fertile $($ present/not fertile) & Fertile & Staminodium (fertile) \\
Zingiberaceae & Absent & Staminodium & Staminodium \\
\hline
\end{tabular}

Note. The original character states are in normal type face or, where incorrect, bold. Reinterpreted character states are in italics. Kress et al.'s (2001) character 18 had to be split into two characters to represent the organ-by-organ homologies established in this article.

of subtending bracts and bracteoles. The variable organ number in Philodendron may thus be a consequence of the partitioning of an unpatterned apex into a number of primordia. If this is true, the number of primordia formed on an apex should be correlated with the size of the apex (Green 1994). For instance, the number of carpels in Potamogeton seems to depend on the relationship between the size of the primordia and the size of the apex (Charlton and Posluszny 1991). Inspection of published photographs of Philodendron shows that differences in the size of floral apices are indeed seen in this species, both before and during organogenesis (figs. 18, 19 in Barabé et al. 2000). The fact that the organ primordia form simultaneously in this species is also predicted on the basis of biophysical principles (Green 1985, 1994).

Although the formation of organs on a free, unpatterned apex is interesting, it does not correspond to the patterns of organogenesis found in the Zingiberales. Organ position in the cincinnus and flowers of Hedychium, Phenakospermum, and Heliconia is correlated with the positions of prior organs and may be influenced by them (Kirchoff 2000; this study). Green (1988) has dealt with a situation almost identical to that described in Hedychium in his study of cincinnus development and flower formation in Echeveria derenbergii (Crassulaceae). The cincinni of this species differ from those of Hedychium in that they are derived from a dichasium and, thus, possess a second, very small prophyll inserted opposite the first. The presence of this second prophyll deforms the shape of the young flower and may influence the position of the first sepal (fig. 22 in Green 1988). Its presence, along with the size of the apex, may also influence the formation of five instead of three sepals. In other respects, the biophysical influences on organ position described by Green (1988) seem to apply to organogenesis in Hedychium (Kirchoff 2000). The development of the cincinnus itself seems almost identical in these two species. These considerations make it clear that Hofmeister's rule can provide a useful summary of the biophysical constraints discussed by Green (1985, 1988, 1994, 1996, 1999) and that these constraints have relevance to floral as well as vegetative axes.

\section{Acknowledgments}

Portions of the data presented here were collected while I was a research associate at Fairchild Tropical Garden, Miami. I thank Dr. Jack Fisher and the personnel of Fairchild Tropical Garden for their support during my work at the Garden. Keith Wolliams and the staff of the Harold H. Lyon Arboretum and the Herbarium staff of the Bishop Museum, Oahu, Hawaii, made their facilities available and provided material for this study. Michelle Gibson, then an undergraduate at the University of North Carolina at Greensboro (UNCG), took most of the SEMs, and Tim Plowman provided figure $4 A$. This article is based on work partially supported by the National Science Foundation under grants BSR-8307103 and BSR-880178 and by two Research Council grants from UNCG.

\section{Literature Cited}

Atela P, C Golé, S Hotton 2002 A dynamical system for plant pattern formation: a rigorous analysis. Nonlinear Sci 12:641-676.

Barabé D, C Lacroix, B Jeune 2000 Development of the inflorescence and flower of Philodendron fragrantissimum (Araceae): a qualitative and quantitative study. Can J Bot 78:557-576.

Berlyn GP, JP Miksche 1976 Botanical microtechnique and cytochemistry. Iowa State University Press, Ames. 326 pp.

Bowman JL 1997 Evolutionary conservation of angiosperm flower development at the molecular and genetic levels. J Biosci 22: 515-527.

Bowman JL, DR Smyth, EM Meyerowitz 1989 Genes directing flower development in Arabidopsis. Plant Cell 1:37-52.

Braun A 1831 Vergleichende Untersuchung über die Ordnung der Schuppen an den Tannenzapfen als Einleitung zur Untersuchung der Blattstellung überhaupt. Nova Acta Acad Leopold Carol 15: 195-402, 34 pls.

Carpenter R, E Coen 1990 Floral homeotic mutations produced by transposon-mutagenesis in Antirrhinum majus. Genes Dev 4: 1483-1493.

Charlton WA, AD Macdonald, U Posluszny, CP Wilkins 1989 Additions to the technique of epi-illumination light microscopy for the study of floral and vegetative apices. Can J Bot 67:1739-1743.

Charlton WA, U Posluszny 1991 Meristic variation in Potamogeton flowers. Bot J Linn Soc 106:265-293.

Derstine KS, SC Tucker 1991 Organ initiation and development of inflorescences and flowers of Acacia baileyana. Am J Bot 78: 816-832.

Douady S 1998 The selection of phyllotactic patterns. Pages 335-358 in RV Jean, D Barbé, eds. Symmetry in plants. World Scientific, Singapore.

Eichler AW 1875 Blüthendiagramme. Engelmann, Leipzig. 347 pp.

Green PB 1985 Surface of the shoot apex: a reinforcement-field theory for phyllotaxis. J Cell Sci Suppl 2:181-201.

— 1988 A theory for inflorescence development and flower for- 
mation based on morphological and biophysical analysis in Echeveria. Planta 175:153-169.

1994 Connecting gene and hormone action to form, pattern and organogenesis: biophysical transductions. J Exp Bot 45: $1175-1788$.

1996 Transductions to generate plant form and pattern: an essay on cause and effect. Ann Bot 78:269-281.

1999 Expression of pattern in plants: combining molecular and calculus-based biophysical paradigms. Am J Bot 86:1059-1076.

Hernández L, PB Green 1993 Transductions for the expression of structural pattern. Plant Cell 5:1725-1738.

Hofmeister W 1868 Allgemeine morphologie der Gewächse. Engelmann, Leipzig. 664 pp.

Jean RV 1984 Mathematical approach to pattern and form in plant growth. Wiley, New York. 222 pp.

Jean RV, Barabé D 1998 Symmetry in plants. World Scientific, Singapore. 835 pp.

Johansen DA 1940 Plant microtechnique. McGraw-Hill, New York. $523 \mathrm{pp}$.

Kirchoff BK 1997 Inflorescence and flower development in the Hedychieae (Zingiberaceae): Hedychium. Can J Bot 75:581-594.

1998 Inflorescence and flower development in the Hedychieae (Zingiberaceae): Scaphochlamys kunstleri (Baker) Holttum. Int J Plant Sci 159:261-274.

2000 Hofmeister's rule and primordium shape: constraints on organ position in Hedychium coronarium (Zingiberaceae). Pages 75-83 in KL Wilson, DA Morrison, eds. Monocots: systematics and evolution. CSIRO, Collingwood.

2001 Character description in phylogenetic analysis: insights from Agnes Arber's concept of the plant. Ann Bot 88:1203-1214.

Kodak 1983 Kodak technical pan film 2415. Eastman Kodak pamphlet P-255. Eastman Kodak, Rochester, N.Y.

Kress WJ 1990 The phylogeny and classification of the Zingiberales. Ann Mo Bot Gard 77:698-721.

1995 Phylogeny of Zingiberanae: morphology and molecules. Pages 443-460 in PJ Rudall, PJ Crib, DF Cutler, CJ Humphries, eds. Monocotyledons: systematics and evolution. Royal Botanic Gardens, Kew.

Kress WJ, LM Prince, WJ Hahn, EA Zimmer 2001 Unraveling the evolutionary radiation of the families of the Zingiberales using morphological and molecular evidence. Syst Biol 50:926-944.

Kunze H 1985 Die infloreszenzen der Marantaceen und ihr Zusammenhang mit dem Typus der Zingiberales-Synfloreszenz. Beitr Biol Pflanz 60:93-140.

Lacroix C, R Sattler 1988 Phyllotaxis theories and tepal-stamen superposition in Basella rubra. Am J Bot 75:906-917.

Lane IE 1955 Genera and generic relationships in Musaceae. Mitt Bot Staatssamml Muench 13:114-131.

Luo D, R Carpenter, C Vincent, L Copsey, E Coen 1996 Origin of floral asymmetry in Antirrbinum. Nature 383:794-799.

Lyndon RF 1978a Flower development in Silene: morphology and sequence of initiation of primordia. Ann Bot 42:1343-1348.

$1978 b$ Phyllotaxis and the initiation of primordia during flower development in Silene. Ann Bot 42:1349-1360.

Posluszny U, MG Scott, R Sattler 1980 Revisions in the technique of epi-illumination light microscopy for the study of floral and vegetative apices. Can J Bot 58:2491-2494.

Postek MT, SC Tucker 1976 A new short chemical dehydration method for light microscopy preparations of plant material. Can J Bot 54:872-875.

Ramírez-Domenech JI, SC Tucker 1989 Phylogenetic implications of inflorescence and floral of ontogeny of Mimosa strigillosa. Am J Bot 76:1583-1593.

Richards FJ 1951 Phyllotaxis: its quantitative expression and relation to growth in the apex. Philos Trans R Soc Lond B Biol Sci 235: 509-564.

Rutishauser R 1981 Blattstellung und Sprossentwicklung bei Blütenpflanzen unter besonderer Berücksichtigung der Nelkengewäche Caryophyllaceen s.l. Diss Bot 62:1-166.

1999 Polymerous leaf whorls in vascular plants: developmental morphology and fuzziness of organ identities. Int J Plant Sci 160(suppl):S81-S103.

Rutishauser R, R Sattler 1985 Complementarity and heuristic value of contrasting models in structural botany. I. General considerations. Bot Jahrb Syst Pflanzengesch Pflanzengeogr 107:415-455.

Sattler R 1968 A technique for the study of floral development. Can J Bot 46:720-722.

Schumann K 1900 Musaceae. Das Pflanzenreich IV. 45. Engelmann, Leipzig. 45 pp.

Schwarz-Sommer Z, P Huijser, W Nacken, H Saedler, H Sommer 1990 Genetic control of flower development: homeotic genes of Antirrhinum majus. Science 250:931-936.

Snow M, R Snow 1962 A theory of the regulation of phyllotaxis based on Lupinus Albus. Philos Trans R Soc Lond B Biol Sci 244: 483-513.

Tucker SC 2000a Evolutionary loss of sepals and/or petals in detaroid Legume taxa Aphanocalyx, Brachystegia, and Monopetalanthus (Leguminosae: Caesalpinioideae). Am J Bot 87:608-624.

$2000 b$ Floral development in tribe Detarieae (Leguminosae: Caesalpiniodeae): Amberstia, Brownea, Tamarindus. Am J Bot 87: 1385-1407.

- 2001a Floral development in Schotia and Cynometra (Leguminosae: Caesalpinioideae: Detarieae). Am J Bot 88:1164-1180.

— $2001 b$ The ontogenetic basis for missing petals in Crudia (Legumonisae: Caesalpinioideae: Detarieae). Int J Plant Sci 162: 83-98.

- 2002a Comparative floral ontogeny in Detarieae (Leguminosae: Caesalpinioideae). 1. Radially symmetrical taxa lacking organ suppression. Am J Bot 89:875-887.

$2002 b$ Comparative floral ontogeny in Detarieae (Leguminosae: Caesalpinioideae). 2. Zygomorphic taxa with petal and stamen suppression. Am J Bot 89:888-907.

Tucker SC, CH Stirton 1991 Development of the cymose inflorescence, cupulum and flower of Psoralea pinnata (Leguminosae: Papilionoideae: Psoraleeae). Bot J Linn Soc 106:209-227.

Wagenitz G 1996 Wörterbuch der botanik. Fisher, Jena. 532 pp.

Weberling F 1989 Morphology of flowers and inflorescences. Cambridge University Press, Cambridge. 405 pp.

Winkler H 1930 Musaceae. Pages 505-541 in A Engler, ed. Die natürlichen pflanzenfamilien. Engelmann, Leipzig. 